\title{
Global DNA Methylation Patterns and Gene Expression Associated with Obesity-Susceptibility in Offspring of Pregnant Sprague-Dawley Rats Exposed to BDE-47 and BDE-209
}

Byeong-Min Park, Ok-Jin Yoon, Do-Hoon Lee

Department of Laboratory Medicine, Research Institute and Hospital, National Cancer Center, Goyang, Korea

\section{임신 중 BDE-47 및 BDE-209에 노출된 어미와 새끼 Sprague-Dawley 랫드의 Global DNA 메틸화 양상과 비만 감수성과 연관된 유전자 발현}

박병민, 윤옥진, 이도훈

국립암센터 진단검사의학과

\begin{abstract}
Persistent organic pollutants (POPs) can affect epigenetic mechanisms and obesity development. Polybrominated diphenyl ethers (PBDEs) - widely used to make flames - are one of the important POPs. Prenatal exposure to endocrine disrupting chemicals (EDCs), such as POPs, may affect global DNA methylation in long interspersed nuclear elements ( $L I N E-1)$, increasing the risk of obesity later in life. Therefore, pregnant Sprague-Dawley (SD) rats were used to elucidate whether BDE-47 and BDE-209 transferred through placenta and breast milk cause epigenetic changes in LINE-1 and increase genetic susceptibility to obesity as obesogen during the developmental periods. Global DNA methylation in LINE- 1 and gene expression related to obesity were measured in dams and offspring, using a methylation-sensitive high resolution melting analysis (MS-HRM) and direct bisulfite sequencing and quantitative real time polymerase chain reaction (qPCR), respectively. The results of MS-HRM showed global DNA hypomethylation patterns in LINE- 1 of exposed offspring (2 of total 4) at PND 4, but bisulfite sequencing showed no difference in both the exposed and non-exposed groups. Gene expression in dams related to $\beta$-oxidation pathway and those related to adipokines showed different patterns between the two groups. On the contrary, gene expressions of offspring showed a similar pattern. Gene expressions related to $\beta$-oxidation pathway and obesity were significantly increased when compared with 'at birth', but not PPAR $-\alpha$. In conclusion, this study demonstrated the possibility that co-exposure to BDE-47 and BDE-209via the placenta and breast milk-may affect epigenetic changes and modulate gene expression levels related to obesity.
\end{abstract}

Key words: Polybrominated diphenyl ethers, Epigenetics, DNA methylation, Obesity, Beta-oxidation, Adipokines
Corresponding author: Byeong-Min Park Department of Laboratory Medicine, Research Institute and Hospital, National Cancer Center, 323 Ilsan-ro, Ilsandong-gu, Goyang 10408, Korea

Tel: 82-31-920-1320

Fax: 82-31-920-1337

E-mail: hermani@ncc.re.kr

Received: December 27, 2016 Revised $1^{\text {st. }}$ : February 13, 2017 Revised $2^{\text {nd }}$ : February 14, 2017 Accepted: February 14, 2017 


\section{INTRODUCTION}

Persistent organic pollutants (POPs) are organic chemical substances affecting endocrine, immune, reproductive and nervous systems and show the characteristics of the bioaccumulation, biological persistence, toxicity and long-distance mobility in the environment [1]. The major types of POPs are organochlorine pesticides (OCPs), polychlorinated biphenyls (PCBs) and polybrominated diphenyl ethers (PBDEs) [2]. PBDEs which are significantly elevated in blood among POPs are a class of brominated frame retardant additives found in a variety of commercial products including computers, television sets, furniture and textile in everyday life [3]. Since PBDEs are common in a variety of commercial products, those mothers exposed to PBDEs through diet, air or household dust could have bioaccumulated the chemicals in the system, mainly in adipose tissue and passed them on to their children via placenta and breast milk [4]. PBDEs that may be present in the body, as well as the environment can cause thyroid hormone disruption, neurobehavioral toxicity and for some congeners, possibly even cancer [5]. Endocrine disrupting compounds (EDCs) are chemicals that interfere with the hormone systems and induce adverse effect on reproductive, neurological and immunological system [6]. POPs belong to EDCs in a broad sense because POPs act like EDCs in the system and effect on progression of obesity and diabetes [7]. EDCs are called obesogens in the case of obesity and they increase the rate of childhood obesity when there is exposure during prenatal and child development [8]. Since their action regulates lipid metabolism and adipogenesis which promotes obesity, some scientific data suggested a link between environmental chemical exposure and obesity [9].

Epigenetics modulates gene expression without actually changing the DNA sequence by methylation patterns [10]. DNA methylation is a process that methyl radical is added to the 5' position of cytosine DNA and targets primarily the cytosine residues in CpG dinucleotide. Unmethylated or hypomethylated DNA sequence results in transcription and mRNA expression, which allows binding of the transcription factors at its binding site called the promoter. If the promoter region become methylated, hypermethylated DNA sequence obstructs binding of the transcription factors and resulting in gene silencing [11]. In contrast to promoter region, long interspersed element-1 (LINE-1 or L1) and short interspersed elements (SINEs) called repeated sequences (aka. repetitive elements) are predominantly hypermethylated [12]. In cancer epidemiology, LINE-1 making up roughly $17 \%$ of the human genome methylation patterns is used as a surrogate marker of global DNA methylation [13]. CpG islands are regions with a high frequency of $\mathrm{CpG}$ sites, which are methylated in repeat sequences of normal cells [14]. On the other hand, LINE- 1 hypomethylation and promoter hypermethylation of a tumor suppressor gene are associated with a higher risk in developing several cancers, having a poorer prognosis and more aggressiveness [15].

Thus, the purposes of present study are to examine the global DNA methylation patterns in offspring of pregnant Sprague-Dawley rats, which are repeatedly exposed to mixture of BDE-47, BDE-209 during developmental periods and to assess whether gene expression associated with obesity makers are different on the period of exposure throughout gestation and lactation so as to elucidate whether maternally transferred BDE-47, BDE-209 can cause epigenetic changes and whether they can increase obesity susceptibility as obesogen in the developmental periods. In addition, this study was conducted with limited materials. Therefore, in this study, we were only able to compare between exposed group and non-exposed groups at PND 4. The results of gene expression associated with obesity-susceptibility in the exposed-group were also compared within the group to see a gradual change according to period.

\section{MATERIALS AND METHODS}

The experiment in present study was carried out by using all samples wrapped with aluminum foil and kept at $-80^{\circ} \mathrm{C}$ deep freezer until analysis. Dams and fetuses/neonates/pups were freeze dried, ground very finely and 
stored in the amber vial. It was approved by the Institutional Animal Care and Use Committee (IACUC) of Seoul National University (SNU-1403120502).

\section{Animals and treatments}

Sixteen pregnant Sprague-Dawley rats on gestation day (GD) 0 were purchased from Orient Bio (Seongnam, Korea). Sixteen pregnant Sprague-Dawley (SD) rats were used and randomly assigned to three different conditions of exposed ( $\mathrm{N}=4$ dams per group) and one non-exposed groups ( $\mathrm{N}=4$ dams). We used the PBDEs as mixture with BDE-47, BDE-209 because they are present in commercial products as mixture form and the most domestically predominant congeners are BDE-47, BDE-209. After 7 days adaption, $\mathrm{SD}$ rats in exposure groups were daily force-fed by gavage with mixture $(2.5 \mu \mathrm{mol} / \mathrm{mL}$ for BDE-209 \& $6 \mathrm{nmol} / \mathrm{mL}$ for $\left.{ }^{13} \mathrm{C}-\mathrm{BDE}-47\right)$ of decabromodiphenyl ether (BDE-209, Wellington Laboratories, Ontario, Canada) and radio-labelled 2,2' ,4,4' -tetrabromodiphenyl ether $\left({ }^{13} \mathrm{C}-\mathrm{BDE}-47\right.$, Wellington Laboratories, Ontario, Canada). The exposed groups on GD 8 were treated by gavage with the mixture of BDE-209 (2.5 $\mu \mathrm{mol} / \mathrm{kg} \mathrm{b.w})$ and ${ }^{13} \mathrm{C}-\mathrm{BDE}-47$ ( $6 \mathrm{nmol} / \mathrm{kg}$ b.w) for 18 consecutive days from GD 8 to postnatal day (PND) 4. Three exposed groups were serially sacrificed at GD 14, birth and PND 4, respectively. The one non-exposed group was treated with corn oil in the same fashion and sacrificed at PND 4. We analyzed whether gene expression levels of obesity makers are different from the period of exposure. To do so, the results of the gene expression between the exposed and the non-exposed groups were compared with PND 4 and the changes of gene expression with different period of exposure were compared among the exposed groups.

\section{Sample collection and analysis}

1) Genomic DNA extraction and bisulfite treatment

Genomic DNA (gDNA) was extracted from specimens of whole liver, brain from dams and tail from offspring stored at $-80^{\circ} \mathrm{C}$ until downstream analysis was performed, using a DNA extraction kit (QIAamp DNA FFPE tissue kit, Qiagen, Hilden, Germany) according to the manufacturer's protocol. The DNA concentration was estimated by measuring absorbance at $260 \mathrm{~nm}$ using a spectrophotometer (NanoDrop 1000, Thermo Scientific, Wilmington, DE, USA). gDNA in dams were extracted from each of the liver, brain. On the other hand, gDNA in offsprings were extracted from tail of neonate, pup and fetal body (only $\mathrm{N}=1$ ). To put it briefly, unmethylated cytosines are converted to uracil by treatment with bisulfite while methylated cytosines are protected. Bisulfite modification of genomic DNA was carried out by using the Bisulfite conversion kit (EZ DNA methylation-lightning kit; Zymo Research, Orange, CA, USA) following the manufacturer's protocol.

2) Methylation-Sensitive High-Resolution Melting Analysis (MS-HRM)

The experiment was performed in 96-well plates (LightCycler $\AA$ 480, Roche Diagnostics, Indianapolis, IN, USA) using a mix reaction (LightCycler $\mathbb{R} 480$ High Resolution Melting Master Mix, Roche Diagnostics, Indianapolis, IN, USA), which contains a DNA intercalating dye, in a final volume of $20 \mu \mathrm{L}$, on a thermocycler instrument (LightCycler® 480II, Roche Diagnostics, Indianapolis, IN, USA). The following primer sets were designed by MethPrimer (http://www.urogene.org/cgi-bin/methprimer/methpri mer.cgi).

Primer sequences in the 5 ' untranslated region (5'UTR) of LINE-1 (GenBank: AH005177.2) are forward; 5'- TTGTTGTAAGAAAGTTGTTTGGTGA-3' and reverse; 5'-CTACAACCTCAAAAATACCCACCTA-3' (Table 1). The reaction mixture contained the master mix $(2 \times), 0.2 \mu \mathrm{M}$ of the primer and $1 \mu \mathrm{L}$ of bisulfite-modified DNA with $3 \mathrm{mM}$ of $\mathrm{MgCl}_{2}$. The cycling conditions used for the assays were as follows: 1 cycle of $95^{\circ} \mathrm{C}(10 \mathrm{~min}), 45$ cycles of $95^{\circ} \mathrm{C}(10 \mathrm{~s})$, $60^{\circ} \mathrm{C}$ for $10 \mathrm{~s}$ and $72^{\circ} \mathrm{C}(10 \mathrm{~s})$, followed by MS-HRM step of $95^{\circ} \mathrm{C}(1 \mathrm{~min})$, followed by cooling at $70^{\circ} \mathrm{C}(1 \mathrm{~min})$; then, the acquisition step started ramping from 70 to $95^{\circ} \mathrm{C}$, rising by $0.2^{\circ} \mathrm{C} / \mathrm{s}$ with 25 acquisitions $/{ }^{\circ} \mathrm{C}$. Commercial standards (Pre-mixed Calibration Standard, EpigenDx, Hopkinton, MA, USA) were used as 0\%, 5\%, 10\%, 25\%, 50\%, $75 \%$ and $100 \%$ methylated control DNA, respectively. Methylation standards were modified by bisulfite according 
Table 1. Primer sequence set of LINE-1

\begin{tabular}{|c|c|c|c|c|}
\hline & Primer sequences & Annealing temperature $\left({ }^{\circ} \mathrm{C}\right)$ & Amplicon size (bp) & Number of $\mathrm{CpG}$ sites \\
\hline Primer set & $\begin{array}{l}\text { F: TTGTTGTAAGAAAGTTGTTTGGTGA } \\
\text { R: CTACAACCTCAAAAATACCCACCTA }\end{array}$ & 60 & 187 & 10 \\
\hline \multicolumn{5}{|c|}{$\begin{array}{l}1 \text { TTCCTGGTTGCTCCGCTGCAGAGAGCCCTGGGCAGCACCCCACGAGCGAACCTGAGCCTC } \\
\quad||::|||||||:|:++:||:|||||||:::||||:||:|::::|++||++||::||||::|+ \\
1 \text { TTTTTGGTTGTTCGTTGTAGAGAGTTTGGGTAGTATTTACGAGGAATTGAGTTC }\end{array}$} \\
\hline \multicolumn{5}{|c|}{ 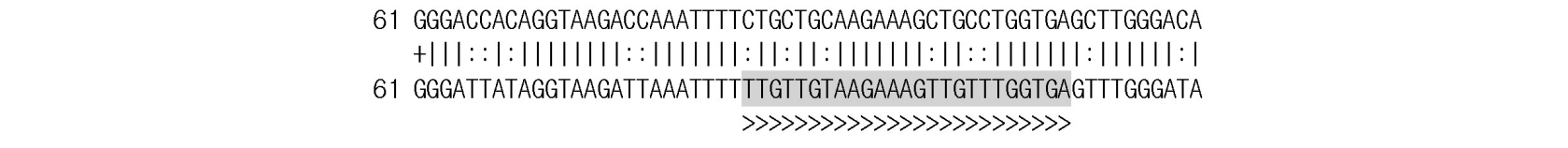 } \\
\hline \multicolumn{5}{|c|}{ 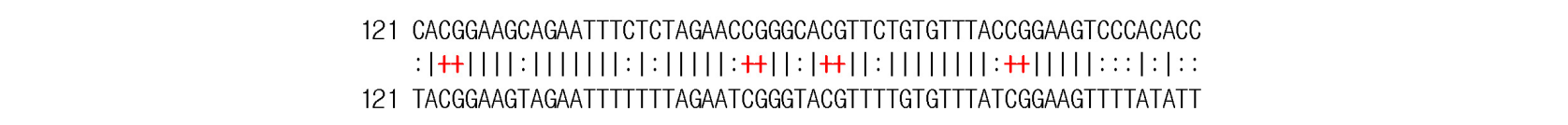 } \\
\hline & 38 & $\begin{array}{lll}61 & 67 & 8\end{array}$ & & \\
\hline \multicolumn{5}{|c|}{ 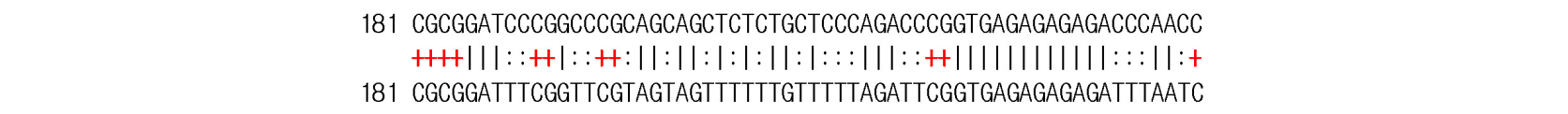 } \\
\hline & $9698 \quad 105 \quad 110$ & 135 & 155 & \\
\hline \multicolumn{5}{|c|}{ 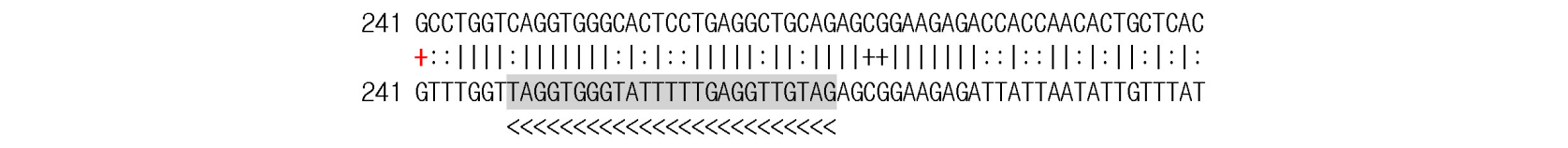 } \\
\hline
\end{tabular}

to the manufacturer's protocol. These standards were included in each experimental run. MS-HRM data were analyzed using the Gene Scanning Software (Roche Diagnostics).

\section{3) Direct bisulfite sequencing}

To confirm MS-HRM results, DNA sequencing was performed by Cosmo Genetech, Seoul, Korea. The brief protocol was described as below. PCR products from MS-HRM reactions were used as templates for sequencing reactions. The DNA amplicons were sequenced using the same PCR primers for MS-HRM reactions with the Big Dye Terminator v3.1 cycle sequencing kit (Thermo Fisher Scientific, Waltham, MA, USA). The products were cleaned with the Magnesi ${ }^{\mathbb{R}}$ GREEN (Promega, Madison, WI, USA) and resolved with the ABI 3730xl genetic analyzer (Thermo Fisher Scientific). The data were analyzed using the AB1 data collection software v3.0 (Thermo Fisher Scientific), DNASTAR ${ }^{\circledR}$ Lasergene sequence analysis software (DNASTAR, Madison, WI, USA). Additionally, sequence analysis software (Sequencher, Genecodes) was used to observe the peak variation of thymidine (T) and cytosine (C) at CpG sites.

4) RNA isolation and gene expression analysis

For quantitative real time polymerase chain reaction (qPCR), total RNA was extracted from frozen tissues of whole liver from dams and offspring with the RNeasy mini kit (Qiagen, Hilden, Germany) and then reverse transcribed with High-Capacity cDNA reverse transcription kits (Applied Biosystems, Foster City, CA, USA) according to the manufacturer's protocol. The RNA concentration was measured with a spectrophotometer (NanoDrop 1000, Thermo Scientific, Wilmington, DE, USA). qPCR reactions were performed by using TaqMan gene expression assays (Applied Biosystems) for PPAR- $\alpha$ (NM_013196.1), PPAR- $\gamma$ (NM_001145366.1), ACOX 1 (NM_017340.2), TNF- $\alpha$ (NM_012675.3), Adipoq (Rn00595250_m1) and Gapdh (NM_017008.4) in the Applied Biosystems 7500 fast real-time PCR system (Applied Biosystems) (Table 2). 
32 Byeong-Min Park, et al. Epigenetic Changes by Transgenerational Delivery of BDE-47, -209 through Placenta and Breast Milk

Table 2. Genes presented single-tube assays with their respective TaqMan gene expression assay numbers and GenBank

\begin{tabular}{cccc}
\hline Gene symbol & Gene description & TaqMan gene expression assay number & GenBank accession number \\
\hline PPAR $\alpha$ & Peroxisome proliferator-activated receptor $\alpha$ & Rn00566193_ml & NM_013196.1 \\
PPAR $\gamma$ & Peroxisome proliferator-activated receptor $\gamma$ & Rn00440945_ml & NM_001145366.1 \\
ACOX 1 & Acyl-CoA oxidase 1, Palmitoyl & Rn01460628_ml & NM_017340.2 \\
TNF $\alpha$ & tumor necrosis factor & Rn01525860_g1 & NM_012675.3 \\
Adipoq & Adiponectin & NM_144744.3 & Rn00595250_m1 \\
Gapdh & Glyceraldehyde-3-phosphate dehydrogenase & Rn01775763_g1 & NM_017008.4 \\
\hline
\end{tabular}

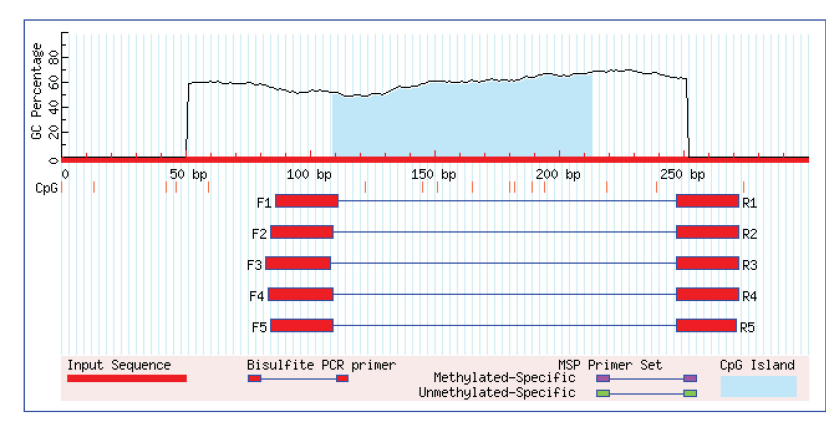

Figure 1. The results of $\mathrm{CpG}$ island by using MethPrimer (Criteria used: Island size >100, GC Percent >50.0, Obs/Exp >0.6). The blue area represents CPG island in LINE-1.

Glyceraldehyde-3-phosphate dehydrogenase (GAPDH) was amplified as a normalizing control. Relative expression was calculated by the $2^{-\Delta \Delta C \mathrm{~T}}$ method.

\section{5) Statistical analysis}

Statistical analysis was performed using STATA version 12 (StataCorp, College Station, TX, USA). Statistical differences between exposed and non-exposed groups were evaluated by the Wilcoxon rank-sum test (non-parametric) to test for significant differences between independent 2 groups. A $p$-values less than 0.05 were considered significant. The results of mRNA expression are given as mean \pm standard deviation (SD).

\section{RESULTS}

\section{The results of MS-HRM show global DNA hypome-} thylation patterns at PND 4 of exposed offspring in LINE-1

To determine if PBDEs exposure through placenta and breast milk alters global DNA methylation, LINE-1 methylation patterns were measured in dams and offspring

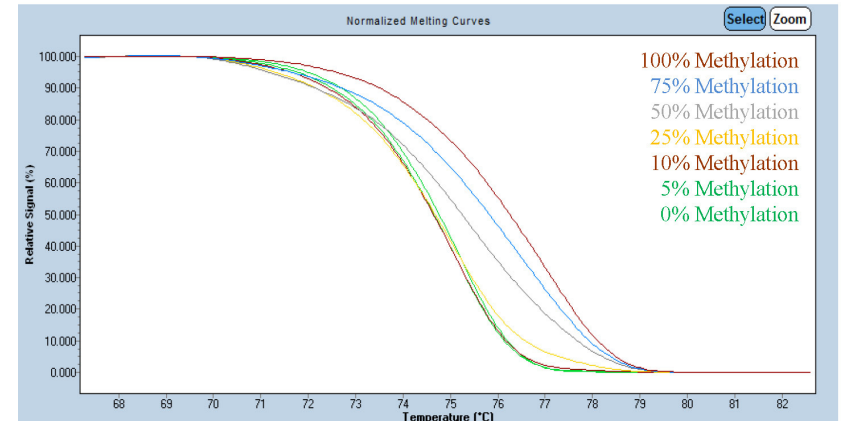

Figure 2. Representative standard melting curves for the determination of methylated DNA. Standard samples, from top to bottom, were $100 \%, 75 \%, 50 \%, 25 \%, 10 \%, 5 \%$ and $0 \%$ methylated.

following exposure to mixture of BDE-47, BDE-209 by gavage for 18 days. The LINE-1 structure has a 5' untranslated region (UTR) with internal promoter activity, two open reading frames (ORFs), a 3'UTR [16]. We found 10 CpG sites in 5' UTR with high GC content by using MethPrimer in order to analyze global DNA methylation patterns (Figure 1).

A standard melting curve presented different methylation rates used to quantify the methylation status of the region (Figure 2). MS-HRM showed the melting curves of all samples were very similar in standard melting curves ranging from $50 \sim 75 \%$, except for exposed offspring ( 2 of total 4) at PND 4 (Figure 3).

\section{Bisulfite sequencing shows no differences in both exposure and control group compared to reference sequence for $L I N E-1$}

Bisulfite sequencing to determine methylation status at CpG dinucleotides was carried out. Interestingly, no difference in sequence was observed between the two groups of samples in exposed and non-exposed offspring at PND 4 compared to reference sequence, even though 
methylated DNA standards as control were changed according to the degree of methylation (Figure 4).

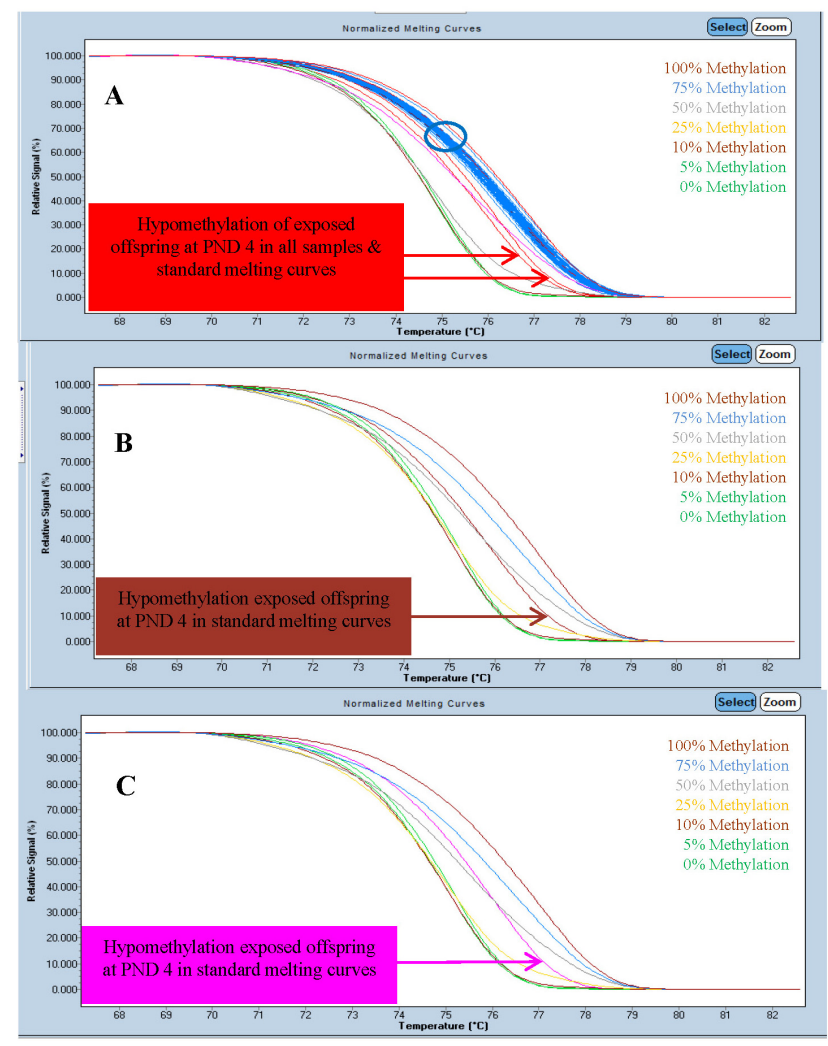

Figure 3. The results of methylation-sensitive high-resolution melting (MS- HRM). In standard melting curves, (A) the melting curves of all samples and (B), (C) the melting curves of exposed offspring (2 of total 4) at PND 4. The arrow indicates more hypomethylated (approximately 25\% to 50\%) melting curve than other melting curves, respectively. (A) The blue circle means all samples of melting curves except exposed offspring (2 of total 4) at PND 4.

\section{Gene expression related to the $\beta$-oxidation pathway and adipokines in dams showed different patterns}

This study was conducted to investigate the genes associated with obesity, whether they are affected by maternal BDE-47, BDE-209 transferred to offspring. The mRNA expressions of PPAR- $\alpha$, ACOX 1 and PPAR- $\gamma$ increased in the exposed dams at birth compared to GD 14 but they showed significant increase only in PPAR $-\gamma$. And they decreased simultaneously at PND 4 (Figure 5). There was a similar pattern of PPAR- $\alpha$ and PPAR- $\gamma$ mRNA expressions gradually increasing from GD 14 to PND 4 and dramatically decreased at PND 4 in exposed dams. ACOX 1 known to be regulated by PPAR $-\alpha$ mRNA expression was a similar pattern to PPAR- $\alpha$ in dams and offspring (Figure 5, 6). So its mRNA expression at PND 4 was also significantly decreased as PPAR- $\alpha$ mRNA expression at PND 4 significantly decreased in dams (Figure 5). In contrast, TNF- $\alpha$ and adiponectin mRNA expression levels showed that up-and-down patterns in consecutively different time point compared to PPAR $-\alpha$ and PPAR $-\gamma$ mRNA expressions in exposed dams (Figure 5). The gene expression of the exposed dams which had the biggest SD was adiponectin linked to the insulin resistance of obesity (Table 3). And it is the true adipokine to be exclusively produced by adipocytes unlike TNF- $\alpha$ which is also secreted by inflammation cell.

\begin{tabular}{|c|c|c|c|c|c|c|c|c|}
\hline & \multicolumn{8}{|c|}{ GpG sites in LINE-1 } \\
\hline & $38-39$ & $61-62$ & $67-68$ & $81-82$ & $96-99$ & $105-106$ & $110-111$ & $135-136$ \\
\hline Reference & $\overline{I A C G G}$ & AICGGG: & ;IACGIT: & $\overline{\mathrm{AICGGA}}$ & $\therefore 1 \operatorname{CGCGGA}$ & $\overline{\overline{I I C G G I T I}}$ & IICGIAG & ICGG I \\
\hline PND 4 day (1) & $\overline{I A \bar{C} G G}$ & 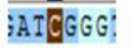 & $\overline{\text { iIACGIT: }}$ & $\overline{: A T C G G A}$ & :ICGCGGA & $\overline{\text { IICGGIII }}$ & $\overline{\text { IICGIAG }}$ & : CEG II \\
\hline PND 4 day (2) & IACGG. & ;AICGGG! & ;IACGIT: & :AICGGA & $: \operatorname{ICGCGGA}$ & IICGGIII & IICGIĀG & : CGG] \\
\hline $0 \% \quad$ Standard & IAT $G G$ & ;AITGGG: & ;IATGIT: & :AI $\bar{T} G G A$ & IIGIGGA & IITGGI: & IITGIAG & I I GGI \\
\hline $50 \%$ Standard & TAGGA & ACGGGG & ICIGII & ACIGGA & CICHIGGA & ICIGGII & IICGIAG & : CGG I \\
\hline $100 \%$ Standard & IACGG. & ¡AICGGG! & ;IACGIT: & :AICGGA & ICGCGGA & IICGGII & IICGIAG & |: CGGI \\
\hline Control 1 & IAC $\bar{C} G$ & ;AICGGG! & ;IACGII: & : $\mathrm{AIC} G \mathrm{C} G \mathrm{~A}$ & $: \overline{\operatorname{CGCG} G A}$ & IICGGII & IICGIAG & : CGG] \\
\hline Control 2 & IACGG & ;AICGGG! & ;TACGIT: & :ATCGGA & & IICGGII। & TICGIAG & I: $\mathrm{CGC}$ \\
\hline
\end{tabular}

Figure 4. The results of bisulfite sequencing of LINE-1 in offspring at PND 4. After bisulfite sequencing, all unmethylated cytosines ( $0 \%$ standard) converted to thymine $(\mathrm{T})$, while all methylated cytosines ( $100 \%$ standard) remained unconverted. Both exposed offspring at PND 4 (2 of total 4) suspected in decreased DNA methylation and non-exposed group did not show the patterns of global DNA hypomethylation compared to reference sequence for LINE-1. 

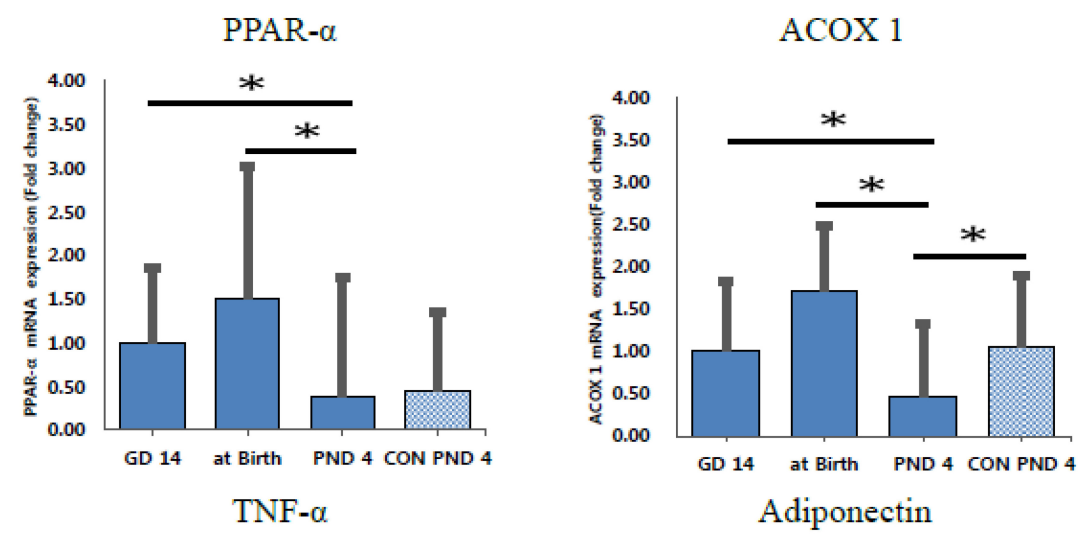

PPAR- $\gamma$
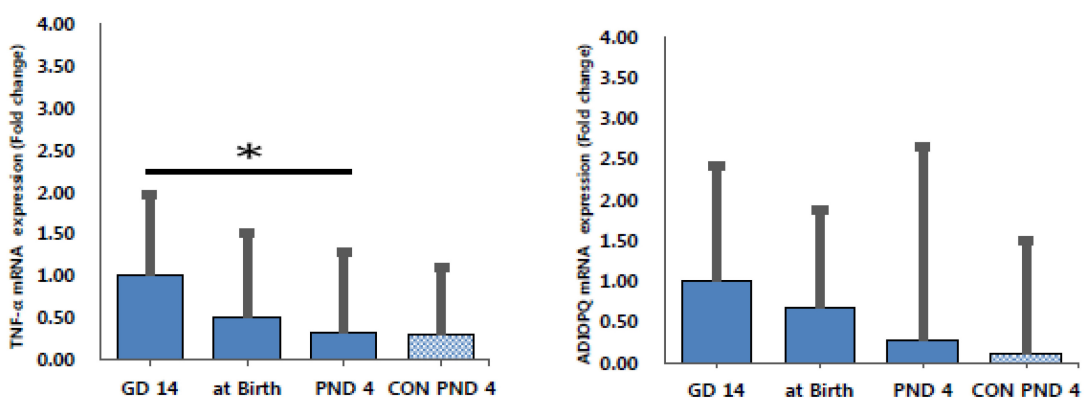

Figure 5. The mRNA gene expression levels associated with obesity in liver of dams at different time points. The error bars represent the standard deviation of the mean. ${ }^{*} p<0.05$ compared to the two points in time.

PPAR- $\alpha$
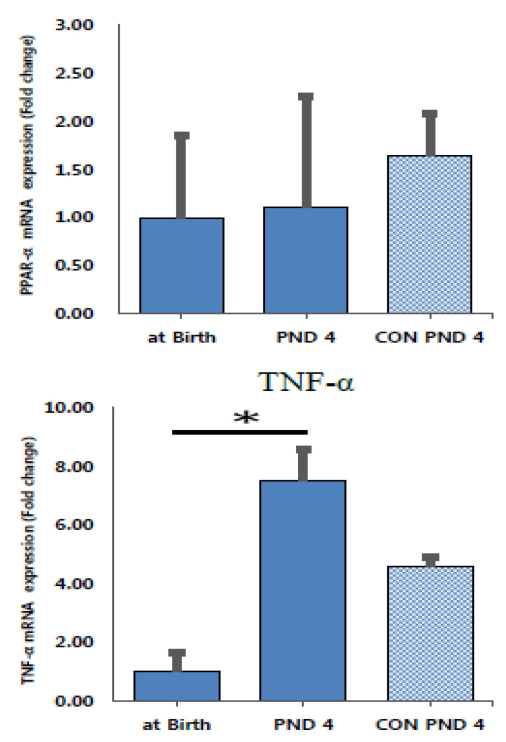

$\operatorname{ACOX} 1$

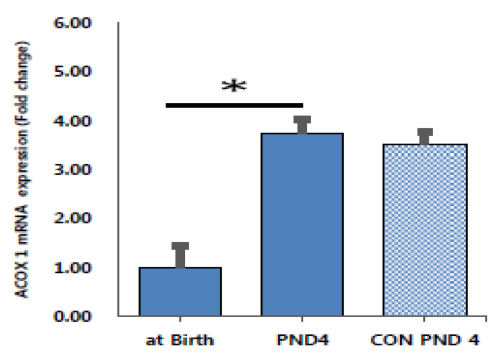

Adiponectin

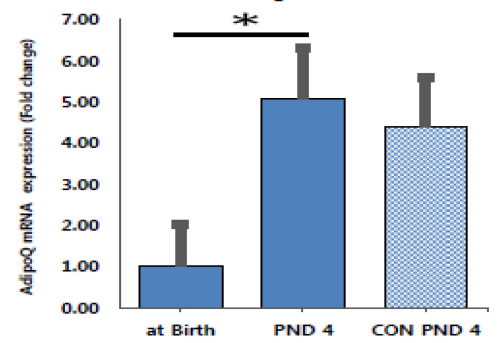

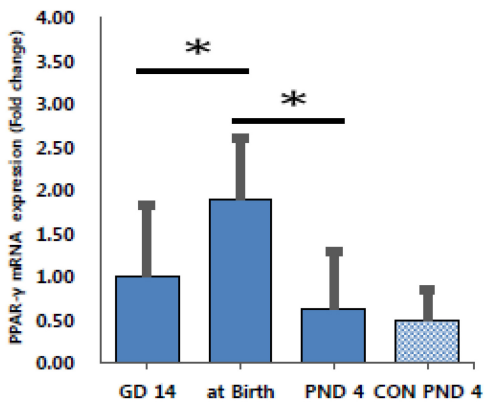

GD 14 at Birth PND 4 CON PND 4

Figure 6. The mRNA gene expression levels associated with obesity in liver of offspring at different time points. The error bars represent the standard deviation of the mean. ${ }^{*} p<0.05$ compared to the two points in time. 
Table 3. The mRNA gene expression in the liver of dams and offspring at different time points

\begin{tabular}{|c|c|c|c|c|c|}
\hline & \multicolumn{4}{|c|}{ Exposed group (Time Points) } & \multirow{2}{*}{$\begin{array}{c}\text { Non-exposed group } \\
\text { (Time Point) } \\
\text { PND } 4\end{array}$} \\
\hline & Genes & at GD 14 & at Birth & PND 4 & \\
\hline \multirow[t]{5}{*}{ Dam } & PPAR $-\alpha$ & $1.00 \pm 0.86$ & $1.50 \pm 1.53$ & $0.38 \pm 1.36$ & $0.45 \pm 0.91$ \\
\hline & ACOX 1 & $1.00 \pm 0.82$ & $1.70 \pm 0.77$ & $0.46 \pm 0.86$ & $1.0 \pm 0.84$ \\
\hline & PPAR $-\gamma$ & $1.00 \pm 0.82$ & $1.89 \pm 0.71$ & $0.63 \pm 0.66$ & $0.51 \pm 0.34$ \\
\hline & TNF- $\alpha$ & $1.00 \pm 0.97$ & $0.50 \pm 1.01$ & $0.32 \pm 0.97$ & $0.29 \pm 0.81$ \\
\hline & Adiponectin & $1.00 \pm 1.42$ & $0.69 \pm 1.19$ & $2.28 \pm 2.38$ & $0.12 \pm 1.39$ \\
\hline \multirow[t]{5}{*}{ Offspring } & PPAR- $\alpha$ & NT & $1.00 \pm 0.85$ & $1.11 \pm 1.15$ & $1.64 \pm 0.45$ \\
\hline & ACOX 1 & NT & $1.00 \pm 0.43$ & $3.74 \pm 0.27$ & $3.51 \pm 0.25$ \\
\hline & PPAR- $\gamma$ & NT & $1.00 \pm 1.47$ & $3.35 \pm 1.38$ & $3.02 \pm 0.64$ \\
\hline & TNF- $\alpha$ & NT & $1.00 \pm 0.65$ & $7.51 \pm 1.10$ & $4.60 \pm 0.30$ \\
\hline & Adiponectin & NT & $1.00 \pm 1.01$ & $5.09 \pm 1.23$ & $4.39 \pm 1.18$ \\
\hline
\end{tabular}

The results represent the calculated fold change (mean \pm SD). GAPDH mRNA levels were used as an internal normalization control. The reference for fold change is 'at GD 14' in exposed group and 'PND 4 of exposed group' in non-exposed group.

Abbreviation: NT, not tested.

\section{Gene expression of offspring related to $\beta$-oxidation pathway and the ones related to obesity showed the up-expression}

The gene expression patterns of offspring exposed through placenta and breast milk were compared and it showed that PPAR- $\alpha$ and ACOX 1 which is related to $\beta$-oxidation pathway have significantly increasing tendency in the exposed group but not PPAR- $\alpha$. And also, PPAR- $\gamma$, TNF- $\alpha$ and Adiponectin which is related to obesity were significantly increased comparing to 'at birth' in the exposed group (Figure 6).

\section{DISCUSSION}

This study was performed to characterize global DNA methylation patterns of $L I N E-1$ repetitive elements in exposed offspring of pregnant $\mathrm{SD}$ rats. The results showed exposed offspring at PND 4 day ( $\mathrm{N}=2$, total 4) have decreased methylation curves compared to standard and other samples curves. Although bisulfite sequencing reactions were performed in order to confirm MS-HRM results, there were no changes in sequencing. However, some experiments in vivo and vitro showed exposure to PBDEs could change DNA methylation patterns. For example, $L I N E^{-1}$ in brain frontal lobe of the offspring exposed to BDE- 47 via dams decreased at low doses rather than high doses [17]. The discrepancy between MS-HRM and bisulfite sequencing in the present study should be further investigated in studies measuring by pyrosequencing for the quantitative methylation analysis in the same samples, since the bisulfite sequencing method may bring out an under-representation of the extent of methylated DNA and the sequencing of short amplicons amplified from a bisulfite modified template can be problematic [18].

Recent evidence shows EDCs are positively associated with adverse health effects by mimicking natural hormones and blocking hormone signaling. Also like natural hormones, these functions at very low doses act on many different tissue types [6]. In the present study, mRNA expression levels of peroxisome proliferator activated receptor- $\alpha, \gamma$ and ACOX 1 in exposed dams from GD 14 to PND 4 formed inverted-U shape. This result according to exposure period in exposed dams could be affected by nonmonotonic dose-response curves of EDCs representing inverted U-shaped curve, which means low-doses are more pronounced activity than high-doses [19].

In this study, the mRNA of both PPAR- $\alpha$ and PPAR- $\gamma$ were simultaneously up-regulated in the liver of exposed dams at the respective same time point. The peroxisome proliferator activated receptors (PPARs), namely, $\alpha, \delta$, and $\gamma$ are a family of nuclear hormone receptors that respond to fatty acids and related ligands. Hormone is largely 
classified in two groups, which are steroid hormone and peptide hormone. Water-soluble peptide hormone affects gene expression by combining with the receptor on cell membrane. Whereas low molecular fat-soluble steroid hormone does so by combining with the nuclear receptor in the nuclear [20]. Specifically, PPAR- $\alpha$ regulates the transcriptional expression of the enzymes involved in fatty acid $\beta$-oxidation [21]. Acyl-CoA oxidase 1 (ACOX 1), the first enzyme of the peroxisomal fatty acid $\beta$-oxidation system, is regulated directly by PPAR- $\alpha$ [22]. As a result, ACOX 1 mRNA was significantly down regulated in exposed dams at PND 4 compared to the non-exposed PND 4 when PPAR- $\alpha$ mRNA was also significantly down expressed at PND 4 compared to exposed dams at birth. In contrast, PPAR- $\gamma$ is the master regulator of adipogenesis and highly expressed in adipose tissues [23]. In murine models for obesity, the mRNA levels of both PPAR- $\alpha$ and PPAR- $\gamma$ were significantly increased in the liver at the same time [24]. Therefore, these data suggest BDE-47, BDE-209 and their metabolites may have a potential effect on a risk factor for obesity as obesogen.

Adipocytes secrete several adipocytokines (signaling proteins), such as TNF- $\alpha$ and adiponectin by the adipose tissue. Not only is TNF- $\alpha$, a proinflammatory cytokine, important players in the state of insulin resistance observed during obesity, but adiponectin is also associated with insulin resistance, regulating both glucose and lipid metabolism [25]. Elevated TNF- $\alpha$ mRNA expression was observed in adipose tissue from obese rodent models and that was found in obese individuals [26]. In present study, TNF- $\alpha$ mRNA expression in exposed dams were gradually decreased from GD 14 to PND 4 according to different time point. This reason for alteration of TNF- $\alpha$ mRNA expression according to the exposure period can be explained by the relationship between PPAR- $\alpha$ and TNF- $\alpha$. Since PPAR- $\alpha$ mRNA expression inversely correlates with TNF- $\alpha$ in rats [27], TNF- $\alpha$ down regulates both mRNA expression of PPAR- $\alpha$ and ACOX 1 associated with peroxisomal $\beta$-oxidation pathway by fatty acids [28].

In previous studies, inverse correlation between adiponectin and TNF- $\alpha$ has been proved by showing that
TNF- $\alpha$ decreases adiponectin mRNA expression in adipocytes [29]. For this reason, if the insulin resistance is increased in body, which induce the increased plasma TNF- $\alpha$ and decreased plasma adiponectin in children with obesity [30]. But this study showed a different result compared to previous results. The mRNA expression of adiponectin in exposed dams showed a similar pattern with the mRNA expression of TNF- $\alpha$ at all different time points. Since they are major adipokines secreted by adipocytes, the declining patterns of them in exposed dams according to the time points could exhibit a similar trend [31]. This discrepancy in previous findings between adiponectin and TNF- $\alpha$ should be further studied.

In this study, the gene expression of the offspring was significantly expressed compared with 'at birth' in exposed group. And then it was suppressed or showed no difference compared with the non-exposed PND 4. Although there are various mechanisms to explain alterations of gene expression in the exposure period, it can be described and found the meaning in terms of epigenetic regulation, namely DNA methylation without DNA sequence modification. Accumulating evidence has indicated the possibility of DNA methylation by EDCs. The promoter of offspring exposed to BPA by dam showed decreased DNA methylation at nine CpG sites compared to control group [32]. Also DNA methylation alterations that directly affect gene expression often occur in the $\mathrm{CpG}$ sites located in the promoter regions of the genes [33]. The increased gene expression of PPAR 2 inducing adipocyte differentiation accompanied after BDE-47 exposure was related to a decreased methylation status of the PPAR 2 promoter in 3T3-L1 cells [34]. The cohort study to examine the impact of prenatal exposure to PBDEs showed decreased cord blood TNF- $\alpha$ promoter methylation associated with high maternal BDE-47 exposure [35]. Recent study has shown the promoter of adiponectin known to play an important role in energy homeostasis is hypermethylated in obese mice. These causes are to have an active TNF- $\alpha$ induced obesity activates DNA methyltransferase 1 (DMNT1), which induced DNA hypermethylation at the particular region (R2; positioned $1 \mathrm{~kb}$ upstream of the transcription 
start site) of adiponectin promoter, resulting in suppression of adiponectin gene expression in adipocyte. In this perspective, methylation analysis of the respective gene promoters should be further investigated in order to explain the gene expression patterns exposed to PBDEs by epigenetic mechanisms [36].

Epigenetic modifications by nutritional and environmental exposures can be inherited in somatic cells via germline modifications, which affects the phenotypic variation and disease in offspring [37]. In other words, epimutation which does not affect DNA sequence changes occurs during germ cell development and leads to epigenetic inheritance [38]. Increasing evidence shows that prenatal exposure to environmental factors affects developmental pathway and thereby induces permanent changes in gene expression, metabolism and chronic disease susceptibility [39]. As a result, epigenetic dysregulation is found in developmental diseases and cancer and probably affects cardiovascular disease, diabetes, and obesity [40]. For this reason, environmental effect on epigenetics is likely to be most critical during prenatal and early postnatal development.

This study showed the possibility of global DNA methylation in the offspring exposed BDE-47, BDE-209 through placenta and breast milk, even though results from MS-HRM and direct bisulfite sequencing did not show the expected results. It also found that the co-exposure to BDE-47, BDE-209 in dams and offspring SD rat induced different gene expression levels associated $\beta$-oxidation and obesity. Therefore, there are enough evidences to suggest BDE-47, BDE-209 is obesogen since it was proved that co-exposure modulate gene expression depending on various conditions. In particular, it was shown that those genes related to obesity were significantly increased in exposed offspring compared to 'at birth'. Given these findings, we could see the possibility of difference in epigenetic susceptibility to co-exposure to BDE-47, BDE-209 between the dams and offspring. For further study, it should include the epigenetic changes, $\beta$-oxidation and obesity gene expression by PBDEs exposure before pregnancy and increasing breast-feeding period. And then since EDC acts even in very low dose, study with different concentration below 'No Observed Effect Level' (NOEL) is required in regard with methylation and gene expression. The comparison between the exposed and non-exposed group according to the period of exposure is also required. Above all, epigenetic research is needed to be progressed together for the study of endocrine disrupting chemicals that affect obesity-related genes because epigenetics can be involved in the expression of obesity gene by DNA methylation. Collectively, these results provide valuable data for further solution of obesity-related genes affected by PBDEs in epigenetics.

\section{요 약}

잔류성 유기 오염 물질은 후성학적 메커니즘과 비만의 발달 에 영향을 줄 수가 있다. 폴리브롬화 디페닐 에테르는 주요한 잔 류성 유기 오염 물질 중 하나이며, 난연제로 널리 쓰인다. 출생 전 잔류성 유기 오염 물질과 같은 내분비교란물질에 노출시 LINE- 1 (long interspersed nuclear elements)의 global DNA 메틸화와 비만 위험도의 증가에 영향을 미칠 수 있다. 따라서, 이번 연구는 임신한 스프라그-돌리 백서를 이용하여 태반과 모 유를 통하여 전달된 $\mathrm{BDE}-47, \mathrm{BDE}-209$ 가 $L I N E-1$ 에서의 후성 학적인 변화와 obesogen으로서 발달과정에 따른 유전적 비만 감수성의 증가에 영향을 줄수 있는지에 대해서 보고자 하였다. 어미와 새끼에서 LINE- 1 의 광범위 DNA 메틸화와 비만과 관련 된 유전자 발현은 methylation-sensitive high resolution melting analysis (MS-HRM), direct bisulfite sequencing와 quantitative real time polymerase chain reaction (qPCR)을 사용하여 각각 분석하였다. MS-HRM 결과는 출생 후 4 일의 노 출군 새끼에서 (4마리 중 2 마리) $L I N E-1$ 의 광범위 DNA 저메틸 화 양상을 보여주었지만, bisulfite sequencing은 노출군과 비 노출군에서 차이가 없었다. $\beta$-산화 경로와 adipokines과 관련 된 어미의 유전자 발현은 두 그룹간 차이를 보였다. 반면에, 새 끼의 유전자 발현은 비슷한 양상을 나타내었다. $\beta$-산화 경로와 비만과 관련된 유전자 발현 중 PPAR- $\alpha$ 를 제외하고는 출생 시에 유의하게 증가하였다. 결론적으로, 이번 연구는 $\mathrm{BDE}-47$, $\mathrm{BDE}-209$ 의 동시 노출이 태반과 모유를 통해서 새끼에서의 후 성학적인 변화와 비만과 관련된 유전자 발현 변화에 영향을 미 칠 수 있는 것을 보여주었다. 
Acknowledgements: Sprague-Dawley 랫드의 검체를 제공 해 주신 김성균 교수님과 아낌없는 조언을 해주신 이재혁 박사 님께 감사를 드립니다.

Funding: None

Conflict of interest: None

\section{REFERENCES}

1. Schell LM, Gallo MV, Denham M, Ravenscroft J. Effects of pollution on human growth and development: an introduction. J Physiol Anthropol. 2006;25(1):103-112.

2. Jaraczewska K, Lulek J, Covaci A, Voorspoels S, KalubaSkotarczak A, Drews K, et al. Distribution of polychlorinated biphenyls, organochlorine pesticides and polybrominated diphenyl ethers in human umbilical cord serum, maternal serum and milk from Wielkopolska region, Poland. Sci Total Environ. 2006;372(1):20-31.

3. Stapleton HM, Klosterhaus S, Keller A, Ferguson PL, van Bergen $\mathrm{S}$, Cooper E, et al. Identification of flame retardants in polyurethane foam collected from baby products. Environ Sci Technol. 2011;45(12):5323-5231.

4. Costa LG, Giordano G, Tagliaferri S, Caglieri A, Mutti A. Polybrominated diphenyl ether (PBDE) flame retardants: environmental contamination, human body burden and potential adverse health effects. Acta Biomed : Atenei Parmensis. 2008; 79(3):172-183.

5. Aschebrook-Kilfoy B, DellaValle CT, Purdue M, Kim C, Zhang Y, Sjodin A, et al. Polybrominated diphenyl ethers and thyroid cancer risk in the prostate, colorectal, lung, and ovarian cancer screening trial cohort. Am J Epidemiol. 2015;181(11):883-888.

6. Schug TT, Janesick A, Blumberg B, Heindel JJ. Endocrine disrupting chemicals and disease susceptibility. J Steroid Biochem Mol Biol. 2011;127(3-5):204-215.

7. Tang-Peronard JL, Andersen HR, Jensen TK, Heitmann BL. Endocrine-disrupting chemicals and obesity development in humans: a review. Obes Rev. 2011;12(8):622-636.

8. Romano ME, Savitz DA, Braun JM. Challenges and future directions to evaluating the association between prenatal exposure to endocrine disrupting chemicals and childhood obesity. Curr Epidemiol Rep. 2014;1(2):57-66.

9. Janesick A, Blumberg B. Obesogens, stem cells and the developmental programming of obesity. Int J Androl. 2012;35(3): 437-448.

10. Jin B, Li Y, Robertson KD. DNA methylation: superior or subordinate in the epigenetic hierarchy? Genes Cancer. 2011;2(6): 607-617.

11. Herrera BM, Keildson S, Lindgren CM. Genetics and epigenetics of obesity. Maturitas. 2011;69(1):41-9.

12. Beck CR, Garcia-Perez JL, Badge RM, Moran JV. LINE-1 elements in structural variation and disease. Annu Rev Genomics Hum Genet. 2011;12:187-215.

13. An W, Dai L, Niewiadomska AM, Yetil A, O'Donnell KA, Han JS, et al. Characterization of a synthetic human LINE-1 retrotransposon ORFeus-Hs. Mob DNA. 2011;2(1):2.
14. Ostertag EM, Kazazian HH, Jr. Biology of mammalian L1 retrotransposons. Annu Rev Genet. 2001;35(1):501-538.

15. Inamura K, Yamauchi M, Nishihara R, Lochhead P, Qian ZR, Kuchiba A, et al. Tumor LINE-1 methylation level and microsatellite instability in relation to colorectal cancer prognosis. J Natl Cancer Inst. 2014;106(9). pii: dju195. doi: 10.1093/jnci/ dju195.

16. Martin SL. The ORF1 protein encoded by LINE-1: structure and function during L1 retrotransposition. J Biomed Biotechnol. 2006;2006(1):45621.

17. Byun HM, Benachour N, Zalko D, Frisardi MC, Colicino E, Takser L, et al. Epigenetic effects of low perinatal doses of flame retardant BDE-47 on mitochondrial and nuclear genes in rat offspring. Toxicology. 2015;328:152-159.

18. Wojdacz TK, Moller TH, Thestrup BB, Kristensen LS, Hansen LL. Limitations and advantages of MS-HRM and bisulfite sequencing for single locus methylation studies. Expert Rev Mol Diagn. 2010;10(5):575-580.

19. Welshons WV, Thayer KA, Judy BM, Taylor JA, Curran EM, vom Saal FS. Large Effects from Small Exposures. I. Mechanisms for Endocrine-Disrupting Chemicals with Estrogenic Activity. Environ Health Perspect. 2003;111(8):994-1006.

20. Lee DH. Endocrine disrupting chemicals and environmental diseases. J Korean Med Assoc. 2012;55(3):243-249.

21. Kersten S, Desvergne B, Wahli W. Roles of PPARs in health and disease. Nature. 2000;405(6785):421-424.

22. Tugwood JD, Issemann I, Anderson RG, Bundell KR, Mcpheat WL, Green S. The mouse peroxisome proliferator activated receptor recognizes a response element in the 5 flanking sequence of the rat acyl coa oxidase gene. Embo J. 1992;11(2): 433-439.

23. Rosen ED, Sarraf P, Troy AE, Bradwin G, Moore K, Milstone DS, et al. PPAR gamma is required for the differentiation of adipose tissue in vivo and in vitro. Mol Cell. 1999;4(4):611-617.

24. Memon RA, Tecott LH, Nonogaki K, Beigneux A, Moser AH, Grunfeld C, et al. Up-regulation of peroxisome proliferatoractivated receptors (PPAR-alpha) and PPAR-gamma messenger ribonucleic acid expression in the liver in murine obesity: troglitazone induces expression of PPAR-gamma-responsive adipose tissue-specific genes in the liver of obese diabetic mice. Endocrinology. 2000;141(11):4021-4031.

25. Peraldi P, Spiegelman B. TNF- $\alpha$ and insulin resistance: summary and future prospects. Mol Cell Biochem. 1998;182(1-2): 169-175.

26. Ogai K, Matsumoto M, Aoki M, Minematsu T, Kitamura KI, Kobayashi M, et al. Increased level of tumor necrosis factor-alpha (TNF-alpha) on the skin of Japanese obese males: measured by quantitative skin blotting. Int J Cosmet Sci. 2016;38: 462-469.

27. Gelinas DS, McLaurin J. PPAR-alpha expression inversely correlates with inflammatory cytokines IL-1beta and TNF-alpha in aging rats. Neurochem Res. 2005;30(11):1369-1375.

28. Beier K, Völkl A, Fahimi HD. TNF- $\alpha$ downregulates the peroxisome proliferator activated receptor- $\alpha$ and the mRNAs encoding peroxisomal proteins in rat liver. FEBS Lett. 1997;412(2): 385-387.

29. Kern PA, Di Gregorio GB, Lu T, Rassouli N, Ranganathan G. 
Adiponectin expression from human adipose tissue: relation to obesity, insulin resistance, and tumor necrosis factor-alpha expression. Diabetes. 2003;52(7):1779-1785.

30. Yan WJ, Wu J, Mo J, Huang CW, Peng LW, Xu L. Plasma levels of adiponectin and tumor necrosis factor-alpha in children with obesity. Zhongguo dang dai er ke za zhi = Chinese journal of contemporary pediatrics. 2009;11(1):47-50.

31. Balistreri CR, Caruso C, Candore G. The role of adipose tissue and adipokines in obesity-related inflammatory diseases. Mediators Inflamm. 2010;2010:802078.

32. Dolinoy DC, Huang D, Jirtle RL. Maternal nutrient supplementation counteracts bisphenol A-induced DNA hypomethylation in early development. Proc Natl Acad Sci USA. 2007;104(32):13056-13061.

33. Jones PA. Functions of DNA methylation: islands, start sites, gene bodies and beyond. Nat Rev Genet. 2012;13(7):484-492.

34. Kamstra JH, Hruba E, Blumberg B, Janesick A, Mandrup S, Hamers $\mathrm{T}$, et al. Transcriptional and epigenetic mechanisms underlying enhanced in vitro adipocyte differentiation by the brominated flame retardant BDE-47. Environ Sci Techno.
2014; 48(7):4110-4119.

35. Dao T, Hong X, Wang X, Tang WY. Aberrant 5'-CpG methylation of cord blood TNF alpha associated with maternal exposure to polybrominated diphenyl ethers. PloS one. 2015; 10(9):e0138815.

36. Kim AY, Park YJ, Pan X, Shin KC, Kwak SH, Bassas AF, et al. Obesity-induced DNA hypermethylation of the adiponectin gene mediates insulin resistance. Nat Commun. 2015;6:7585.

37. Skinner MK. Environmental epigenetic transgenerational inheritance and somatic epigenetic mitotic stability. Epigenetics. 2011;6(7):838-842.

38. Buiting K, Gross S, Lich C, Gillessen-Kaesbach G, el-Maarri O, Horsthemke B. Epimutations in Prader-Willi and Angelman syndromes: a molecular study of 136 patients with an imprinting defect. Am J Hum Genet. 2003;72(3):571-577.

39. Perera F, Herbstman J. Prenatal environmental exposures, epigenetics, and disease. Reprod Toxicol. 2011;31(3):363-373.

40. Waterland RA, Michels KB. Epigenetic epidemiology of the developmental origins hypothesis. Annu Rev Nutr. 2007;27:363388. 